\title{
Are platinum agents, paclitaxel and irinotecan effective for clear cell carcinoma of the ovary? DNA damage detected with $\mathrm{\gamma H} 2 \mathrm{AX}$ induced by anticancer agents
}

Eriko Takatori ${ }^{1 \dagger}$, Tadahiro Shoji ${ }^{1 *+}$, Seisuke Kumagai ${ }^{1 \dagger}$, Takashi Sawai $^{2 \dagger}$, Akira Kurose ${ }^{3 \dagger}$ and Toru Sugiyama ${ }^{1+}$

\begin{abstract}
Objectives: Differences in the incidences and types of DNA damage induced by antitumor agents for clear cell carcinoma (CCC) were determined in 2 ovarian CCC cell lines using $\mathrm{YH} 2 \mathrm{AX}$.

Material and methods: The antitumor activity of anticancer agents, CDDP, CBDCA, PTX and SN-38, was examined using ovarian clear cell carcinoma cultured cell lines (OVISE and RMG-I). After culture, each cell line was treated with each anticancer agent, the cells were collected, fixed, and then reacted with the anti- $\gamma \mathrm{H} 2 \mathrm{AX}$ antibody. $\gamma \mathrm{H} 2 \mathrm{AX}$ and nuclear DNA were then simultaneously detected by flow cytometry using FITC and propidium iodide, respectively, to determine $\gamma \mathrm{H} 2 \mathrm{AX}$ in each cell cycle phase.
\end{abstract}

Results: After administration of CDDP, DNA damage was frequent in S-phase cells, while cell-cycle arrest occurred in the $\mathrm{G} 1$ and G2/M phases and $\mathrm{YH} 2 \mathrm{AX}$ did not increase in CDDP-resistant cells. Sensitivities to CDDP and CBDCA differed between the two cell lines. The antitumor effect of PTX is induced by G2/M arrest, and combination treatment with CBDCA, inducing DNA damage in G2/M-phase cells, might be effective.

Conclusions: This is the first study in Japan to evaluate the antitumor activity of anticancer agents by focusing on the relationship between the cell cycle and DNA damage using $\mathrm{YH} 2 \mathrm{AX}$ as an indicator. The immunocytochemical method used in this study detects $\mathrm{YH} 2 \mathrm{AX}$, which indicates DNA damage even at very low concentrations and with high sensitivity. Therefore, a promising method of easily and rapidly identifying agents potentially effective against CCC.

Keywords: YH2AX, Clear cell carcinoma, Ovarian cancer, DNA damage, Apoptosis, Chemotherapy

\section{Introduction}

Clear cell adenocarcinoma (CCC), a subtype of epithelial ovarian cancer, is less sensitive to chemotherapy and is thus classified as a refractory ovarian cancer [1]. It has been shown that a combination of carboplatin (CBDCA) and paclitaxel (PTX), a standard therapy for ovarian cancer $[2,3]$, is effective against serous adenocarcinoma and endometrioid adenocarcinoma, with a response rate of approximately $75 \%$, while CCC has lower response rates

\footnotetext{
* Correspondence: tshoji@iwate-med.ac.jp

${ }^{\dagger}$ Equal contributors

1 Department of Obstetrics and Gynecology, Iwate Medical University School of Medicine, 19-1, Uchimaru, Morioka, Iwate 020-8505, Japan

Full list of author information is available at the end of the article
}

ranging from $18 \%$ to $50 \%$ [4]. The incidence of CCC has been increasing and is now $25 \%$ in Japan, while that in Europe is $5-6 \%$. As yet, no treatment for this histological subtype of ovarian cancer has been established. Histopathology remains the gold standard for classifying epithelial ovarian cancer subgroups; however, there is emerging evidence indicating different genetic and molecular profiles. Consequently, there is no international consensus regarding the necessity of establishing treatment strategies based on histological subtypes. In fact, global clinical trials of CCC and mucinous adenocarcinoma have already begun. Although which cytotoxic agents have true efficacy against CCC remains unknown, small trials in Japan and basic studies have suggested the efficacy of irinotecan

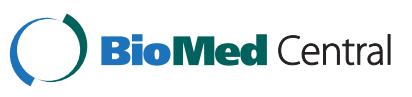


(CPT-11) [5-7]. The Japanese Gynecologic Oncology Group (JGOG) started an international randomized controlled trial (RCT) of cisplatin (CDDP)/CPT-11 therapy with a control arm of CBDCA/TXL (TC) therapy (JGOG3017/GCIG); patient accrual is ongoing and approximately 560 patients had been enrolled in the trial as of July 2010. In addition, an ongoing translational study, as part of the JGOG3017/GCIG trial, also aims to establish an updated treatment strategy.

Nucleosomes, units of chromatin, consist of core histones wrapped in $146 \mathrm{bp}$ of DNA and linker DNA. Core histones are octamers designated $\mathrm{H} 2 \mathrm{~A}, \mathrm{H} 2 \mathrm{~B}, \mathrm{H} 3$ and $\mathrm{H} 4$. Histone $\mathrm{H} 2 \mathrm{AX}$ is a variant of histone $\mathrm{H} 2 \mathrm{~A}$ and accounts for $10-15 \%$ of all variants. When DNA damage occurs, serine 139 of histone H2AX in chromatins on both sides of a damaged site is phosphorylated by two enzymes: ataxia telangiectasia mutated (ATM) protein kinase and by ATM and Rad3 related (ATR) protein kinase [8,9]. Phosphorylated histone H2AX is called $\gamma \mathrm{H} 2 \mathrm{AX}$. Dot $\gamma \mathrm{H} 2 \mathrm{AX}$, which is detectable using $\gamma \mathrm{H} 2 \mathrm{AX}-$ specific antibody, is considered to correspond to specific DNA damage. Therefore, DNA damage can be immunocytochemically detected [10]. DNA damage in individual cells has been detected employing a single-cell DNA gel electrophoresis technique (comet assay), in which the extent and length of the comet's tail indicate the severity of DNA damage. Recently, however, it has become apparent that phosphorylation of histone $\mathrm{H} 2 \mathrm{AX}$, one of the variants of the nucleosome core histone $\mathrm{H} 2 \mathrm{~A}$, can provide a sensitive and reliable marker of DNA damage. More specifically, DNA damage, particularly that involving the formation of DNA double-strand breaks (DSBs), induces phosphorylation of histone H2AX on Ser-139; phosphorylated H2AX is defined as $\gamma \mathrm{H} 2 \mathrm{AX}$. The phosphorylation takes place on $\mathrm{H} 2 \mathrm{AX}$ molecules on both sides of DSBs along a megabase length of DNA. Although DSBs generated during DNA fragmentation in the course of apoptosis also induce $\gamma \mathrm{H} 2 \mathrm{AX}$, the degree of $\gamma \mathrm{H} 2 \mathrm{AX}$ induction in apoptotic cells is much greater than that in primary DSBs induced by antitumor drugs or radiation. The presence of $\gamma \mathrm{H} 2 \mathrm{AX}$ in cells can be detected immunocytochemically in the form of distinct nuclear $\gamma \mathrm{H} 2 \mathrm{AX}$ immunofluorescent foci and each focus is considered to correspond to a single DSB. This immunocytochemical approach has made it possible to assay DNA damage and in situ repair of the chromatin of individual cells. The immunocytochemical approach is significantly more sensitive than the comet assay. The use of multi-parameter flow cytometry in measurements of $\gamma \mathrm{H} 2 \mathrm{AX}$ immunofluorescence allows DNA damage to be correlated with cellular DNA content and, therefore, the cell-cycle phase. Determination of the cell-cycle phase targeted by the drug is of importance in elucidating the mechanism of antitumor drug activity.
In the present study, we conducted flow cytometric bivariate analyses of $\gamma \mathrm{H} 2 \mathrm{AX}$ and DNA contents in two different cell lines of CCC treated with CDDP, CBDCA, PTX or CPT-11 (SN-38), which have been used in the aforementioned international clinical randomized trial targeting CCC, and examined effects of these drugs with regard to the induction of DNA damage, apoptosis and cell-cycle progression vis-à-vis the cell-cycle phase.

\section{Materials and methods \\ Cell culture}

We used two CCC cell lines (OVISE and RMG-I) were obtained from the Health Science Research Resources Bank (Osaka, Japan). OVISE was established from a patient with metastatic disease after completion of six cycles of platinum combination therapy, and was grown in dishes (Becton Drive, Franklin Lakes, NJ, USA) in RPMI1640 medium (Sigma Chemical Co., St Louis, MO, USA) with $10 \%$ fetal bovine serum. RMG-I was established from a chemotherapy-naïve patient with ascites, and was reported to be primary platinum resistant (Table 1) [11]. RMG-I was grown in dishes (Becton Drive) in Ham F-12 medium supplemented with 10\% fetal bovine serum. The media for the two cell lines were supplemented with $100 \mathrm{U} / \mathrm{ml}$ penicillin and $100 \mu \mathrm{g} / \mathrm{ml}$ streptomycin (Meiji Seika Co., Ltd., Tokyo, Japan). All cell lines were maintained at $37^{\circ} \mathrm{C}$ in a humidified atmosphere of $5 \% \mathrm{CO}_{2}$ in air.

\section{Drugs}

CDDP, PTX and SN-38 (CPT-11) were dissolved in dimethyl sulfoxide (DMSO, Sigma); the final concentration of DMSO in the culture medium never exceeded $0.1 \%$ $(w / v)$. CBDCA was dissolved in phosphate-buffered saline (PBS). The concentration of each agent was set to correspond to the blood concentration at a standard clinical dose (Table 2).

\section{Immunohistochemistry}

Both cells floating in the medium and the cells that remained attached after trypsinization were collected and fixed with $1 \%$ methanol-free formaldehyde (Polysciences Inc., Warrington, PA, USA) in PBS at $0{ }^{\circ} \mathrm{C}$ for 15 minutes and post-fixed with $80 \%$ ethanol for at least 2 hours at -20 ${ }^{\circ} \mathrm{C}$. The fixed cells were washed twice in PBS and

Table 1 Clinical biological characteristics of the cell line

\begin{tabular}{ccccc}
\hline $\begin{array}{c}\text { Cell } \\
\text { Line }\end{array}$ & Source & Histopathology & Pretreatment & $\begin{array}{c}\text { Median } \\
\text { doubling time }\end{array}$ \\
\hline OVISE & $\begin{array}{c}\text { Solid } \\
\text { metastatic }\end{array}$ & CCC & CAP $\times 6$ courses & 60 hours \\
\hline RMG- 1 & Ascites & CCC & No & 60 hours \\
\hline
\end{tabular}

CCC; clear cell carcinoma

CAP; cyclophosphamide, doxorubicin, cisplatin 
Table 2 Minimum effective concentration (MEC)

\begin{tabular}{lcc}
\hline & Cmax & MEC \\
\hline PTX & $10 \mu \mathrm{g} / \mathrm{ml}$ & $50 \mathrm{ng} / \mathrm{ml}$ \\
\hline CDDP & $7 \mu \mathrm{g} / \mathrm{ml}$ & $1 \mu \mathrm{g} / \mathrm{ml}$ \\
\hline CBDCA & $55 \mu \mathrm{g} / \mathrm{ml}$ & $10 \mu \mathrm{g} / \mathrm{ml}$ \\
\hline SN-38 & $30 \mu \mathrm{g} / \mathrm{ml}$ & $1 \mathrm{ng} / \mathrm{ml}$ \\
\hline Cmax
\end{tabular}

Cmax; clinical maximum drug concentration.

suspended in a $1 \%(\mathrm{w} / \mathrm{v})$ solution of bovine serum albumin (BSA) (Sigma) in PBS to suppress non-specific antibody binding. The cells were then incubated in $100 \mu \mathrm{l}$ of $1 \%$ BSA containing 1:100 diluted anti-phosphohistone H2AX (Ser-139) monoclonal antibody (Upstate, Lake Placid, NY, USA) for 2 hours at room temperature, washed twice with PBS and resuspended in $100 \mu \mathrm{l}$ of 1:20 diluted fluorescein isothiocyanate (FITC)-conjugated $\mathrm{F}\left(\mathrm{ab}^{\prime}\right)^{2}$ fragment of goat anti-mouse immunoglobulin (Dako, Glostrup, Denmark) for 30 minutes at room temperature in the dark. The cells were then counterstained with $5 \mu \mathrm{g} / \mathrm{ml}$ propidium iodide (PI) (Sigma) in the presence of $100 \mu$ of RNaseA (Sigma) for 30 minutes.

\section{Fluorescence measurements by flow cytometry}

The FITC (green) and PI (red) fluorescence of individual cells in suspension induced by excitation with a 488-nm argon ion laser was measured using a FACScan flow cytometer (Becton-Dickinson, San Jose, CA, USA). The green and red fluorescence from each cell was separated and quantified using standard optics and Cell Quest software (Becton-Dickinson). Ten thousand cells were measured per sample. All experiments were repeated at least three times.

After $\gamma \mathrm{H} 2 \mathrm{AX}$ and DNA staining, the DNA content was represented on the $\mathrm{x}$ axis and the $\gamma \mathrm{H} 2 \mathrm{AX}$ content on the y axis using flow cytometry. The $\gamma \mathrm{H} 2 \mathrm{AX}$ in each cell cycle was determined, thereby allowing the relationships between cell kinetics and DNA damage induced by antitumor agents to be examined.

\section{Results \\ Platinum Agents \\ CDDP}

OVISE cells showed an increase in the number of distinct green dots $(\gamma \mathrm{H} 2 \mathrm{AX}$ foci) after exposure to $10 \mu \mathrm{g} / \mathrm{ml}$ CDDP for $24 \mathrm{~h}$, which indicates that CDDP caused DNA damage (Figure 1). Using folw cytometry, DNA damage was evident from the increase in $\gamma \mathrm{H} 2 \mathrm{AX}$. After 24-hour treatment with CDDP, DNA damage in OVISE and RMG-I was seen gradually in the $S$ phase at concentrations of $100 \mathrm{ng} / \mathrm{ml}$ and $1 \mathrm{ng} / \mathrm{ml}$ (Figure 2A). In both cell lines, treatment with $100 \mathrm{ng} / \mathrm{ml}$ or more CDDP for 24 hours caused DNA damage throughout the cell cycle. The cells with DNA damage gradually underwent apoptosis, as was evident by the presence of cells with markedly elevated $\gamma \mathrm{H} 2 \mathrm{AX}$ and fractional

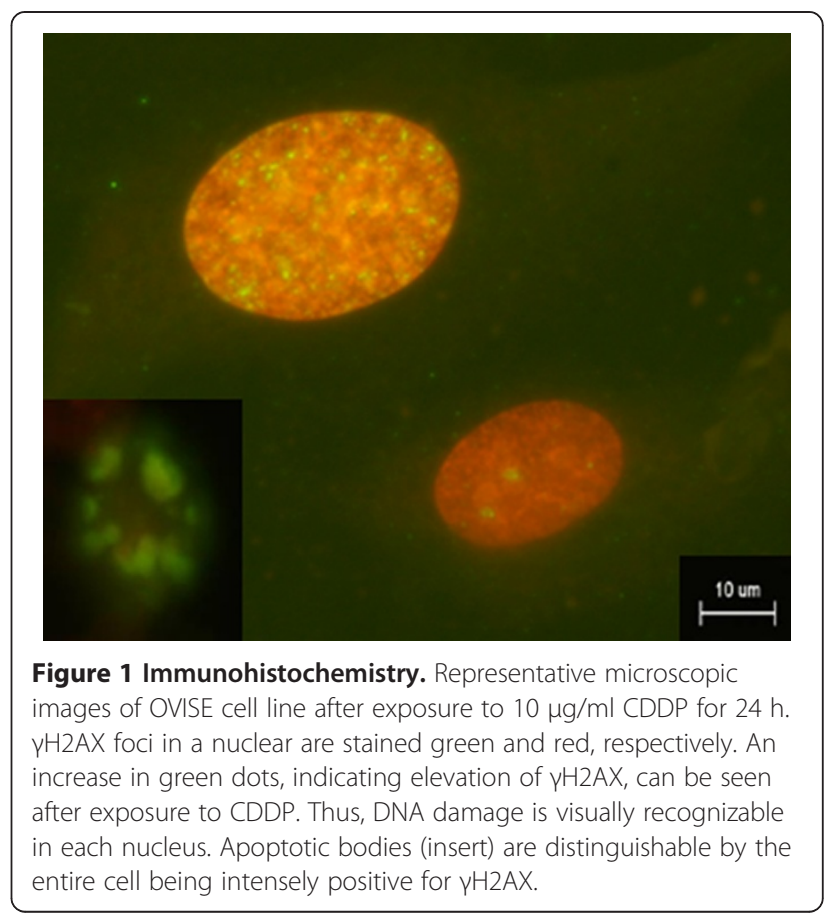

(sub-G1) DNA contents. In OVISE, DNA damage in the S and $\mathrm{G} 2 / \mathrm{M}$ phases after treatment with $100 \mathrm{ng} / \mathrm{ml} \mathrm{CDDP}$ was seen for 24 and 72 hours, respectively (Figure $2 \mathrm{~B}$ ). Although in RMG-I, $100 \mathrm{ng} / \mathrm{ml}$ CDDP caused DNA damage in the $S$ phase, in other phases of the cell cycle it was not apparent even with longer treatment. In both cell lines, the cells with damaged DNA underwent apoptosis. The number of cells in the G2/M phase in OVISE decreased gradually indicating S-phase arrest. . On the other hand, in RMG-I showed G1 and G2/M-phases arrest. RMG-I was found to be less susceptible to DNA damage and subsequent apoptosis than OVISE.

\section{CBDCA}

DNA damage in the $S$ phase was seen gradually after exposure to CBDCA for 24 hours in OVISE and RMG-I lines at $1 \mu \mathrm{g} / \mathrm{ml}$ and $10 \mu \mathrm{g} / \mathrm{ml}$, respectively (Figure 3A). Subsequently, the cells with damaged DNA underwent apoptosis. Gradually both cell lines showed DNA damage in the G2/M phase and underwent apoptosis. OVISE showed S and G2/M- phases arrest, while RMG-I G2/Mphase arrest (Figure 3B).

\section{PTX}

Exposure to $10 \mathrm{ng} / \mathrm{ml}$ or more PTX for 24 hours caused apoptosis without primary DNA damage in both cell lines. (Figure 4A). Although, further apoptotic effects were not seen at doses exceeding $50 \mathrm{ng} / \mathrm{ml}$. PTX induced both cell lines G2/M-phase arrest, but some cells remained 120 hours after exposure without primary DNA damage (Figure 4B). 


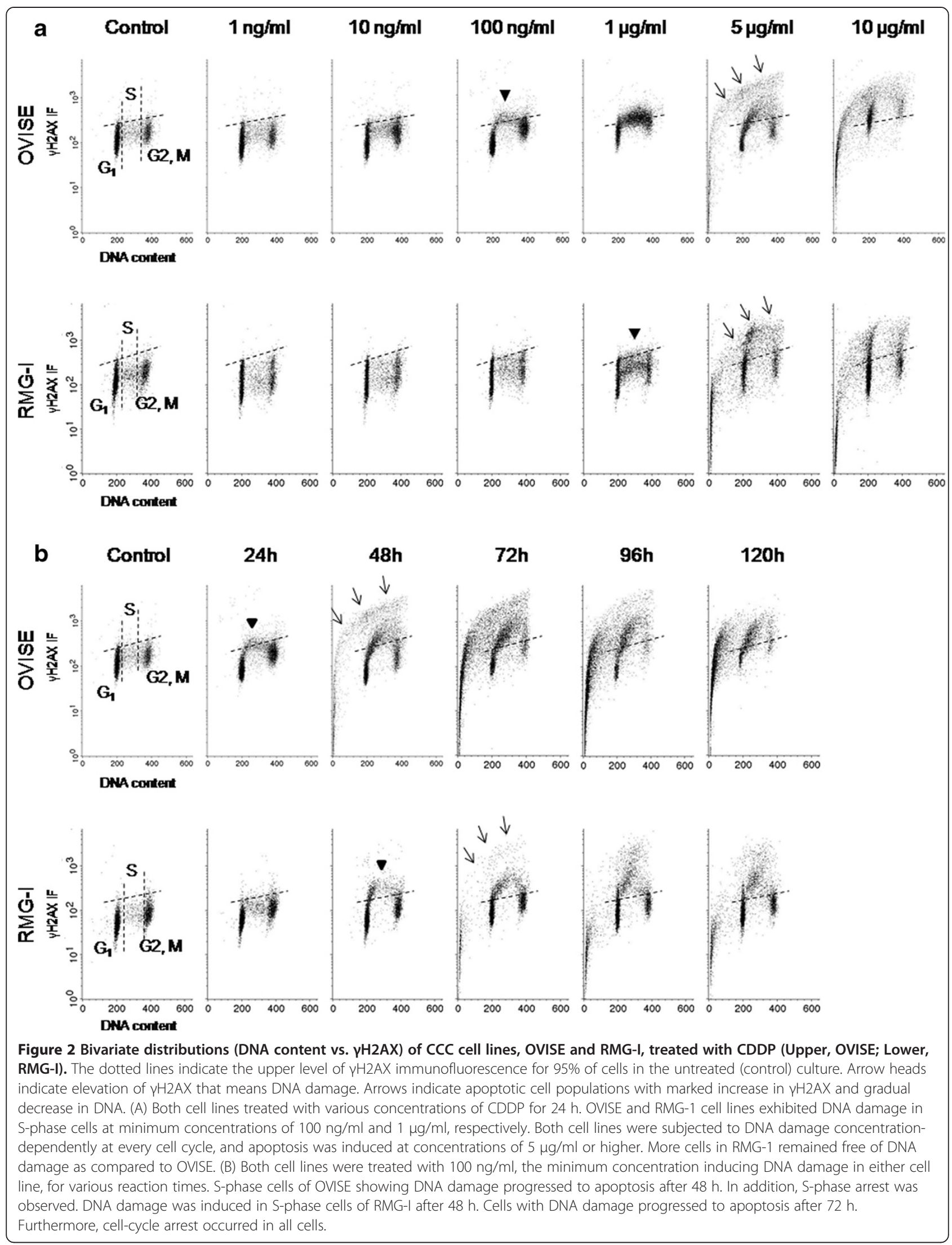




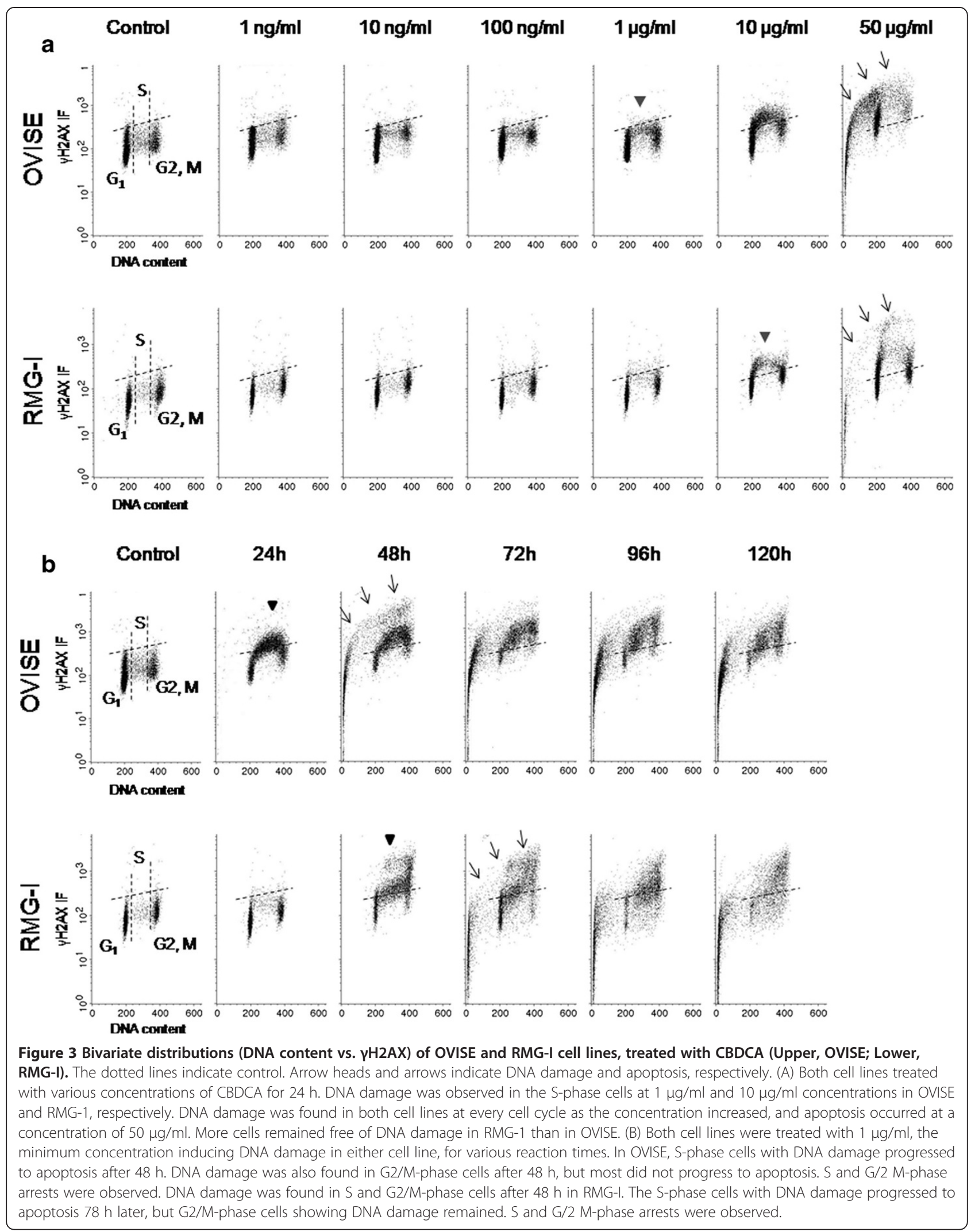




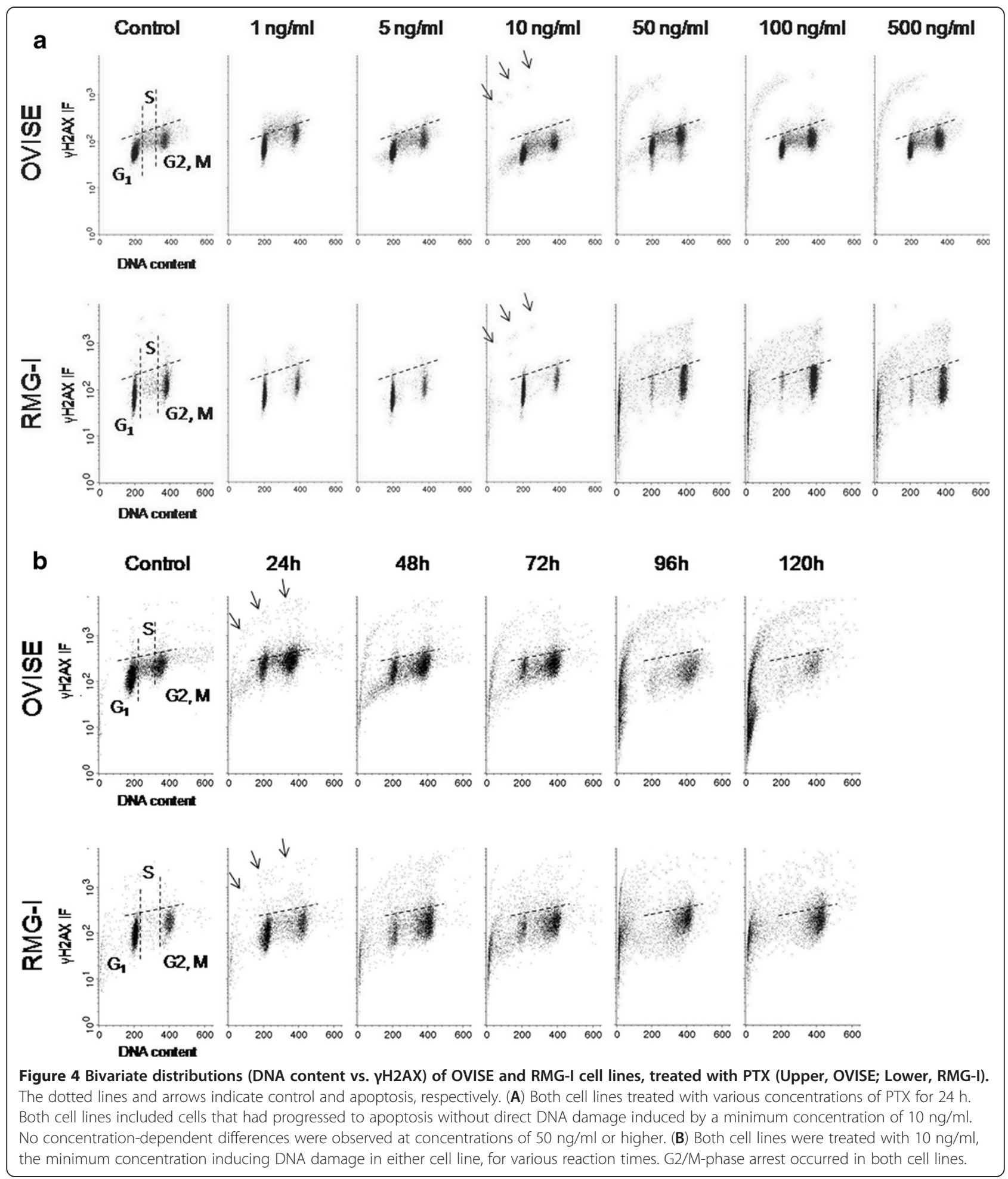

\section{SN-38}

After treatment with $0.5 \mathrm{ng} / \mathrm{ml}$ or more of SN-38 for 24 hours, both cell lines distinguished DNA damage in the $\mathrm{S}$ phase. Nevertheless even $10 \mathrm{ng} / \mathrm{ml}$ which is nearly the clinical maximum blood concentration did not cause apoptosis (Figure 5A). Apoptosis was seen barely 72 hours after exposure to $0.5 \mathrm{ng} / \mathrm{ml} \mathrm{SN}-38$ in a portion of OVISE while in RMG-I after 96 hours (Figure 5B). However, the cells with significant DNA damage remained in the $\mathrm{S}$ phase over 120 hours after exposure. 


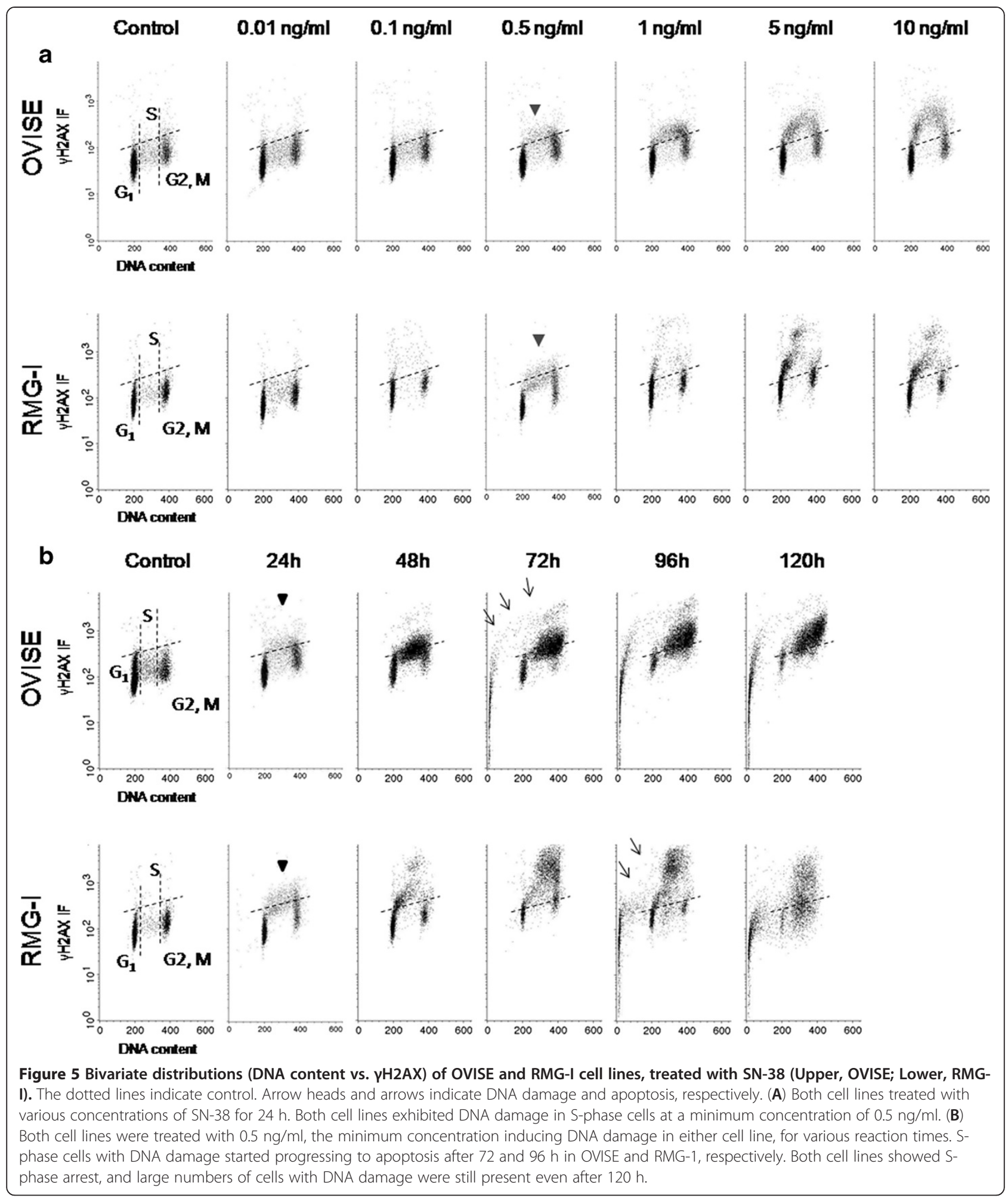

\section{Discussion}

After CDDP administration, DNA damage was observed mainly in the $S$ phase. It is reasonable to assume that the DNA was structurally altered by CDDP, leading to DNA replication fork arrest and ultimately resulting in apoptosis. This result was consistent with a known pharmacological effect of CDDP [12]. In RMG-I, apoptotic cells were minimally increased in the $\mathrm{S}$ phase, moreover the cells showing arrest in the G1 and G2/M phases without DNA damage were increased as 
compared with OVISE. Therefore, the results of the present study support the clinical experience that RMGI is CDDP-resistant [11,13]. After CBDCA administration, DNA damage was seen in the $\mathrm{S}$ and G2/M phases in both cell lines. OVISE contained a remarkable cell population rescued from apoptosis and surviving with DNA damage. On the other hand, most RMG-I cells with DNA damage underwent apoptosis. These results suggest that cell lines respond differently to platinum agents, i.e., RMG-I was CDDP-resistant but responded to CBDCA. PTX directly induced apoptosis in M-phase cells but not via DNA damage, an observation consistent with a known pharmacological effect of PTX, i.e. microtubule inhibition [14]. PTX was confirmed to induce apoptosis through a p53-independent pathway; it was, therefore, expected to have an effect on CCC, in which the p53 mutation is rare $[15,16]$. The mechanism underlying the antitumor effect of PTX is G2/M arrest. Therefore, the combination with CBDCA, an agent inducing DNA damage, in G2/M-phase arrested cells might be effective, at least theoretically. As shown in this study, it is noteworthy that sensitivities to CDDP and CBDCA differed between the CCC cell lines. In practice, CCC is less sensitive to CBDCA/PTX treatment $[4,6,17]$, which is the standard regimen for ovarian cancer. Since the effect of PTX was independent of both the concentration and the response time, these results raise the possibility that repeated administration of PTX at a low dose increases the antitumor effect more than a single administration. These findings support the results of the JGOG3016, i.e. that weekly CBDCA (AUC6)/PTX $\left(80 \mathrm{mg} / \mathrm{m}^{2}\right.$, weekly $\left.\times 3\right)$ is more effective than tri-weekly CBDCA (AUC 6)/PTX $\left(175 \mathrm{mg} / \mathrm{m}^{2}\right)$ treatment [18].

On the other hand, after administration of $\mathrm{SN}-38$, DNA damage occurred in S-phase cells, followed by apoptosis. This confirmed that $\mathrm{SN}-38$ acts as a type I topoisomerase inhibitor [19]. Furthermore, it appears that SN-38 had an effect on the cell cycle because Sphase arrest continued for more than 120 hours. It is, therefore, possible that the improved administration method for SN-38 increases its antitumor effect. Cells rescued from apoptosis remained in S phase with DNA damage; consequently, the efficacy of combining SN-38 with CDDP, which induces DNA damage mainly in Sphase cells, was supported.

In conclusion, the present results suggest that an effective treatment for CCC with a slow growth rate and a low ratio of S-phase cells would be a combination of agents arresting the cell cycle, thereby causing accumulation of cells in the $\mathrm{S}$ phase or the G2/M phase, and agents specifically inducing DNA damage in S-phase cells. The method used in this study allows immunocytochemical detection of $\gamma \mathrm{H} 2 \mathrm{AX}$, which indicates DNA damage even at very low concentrations and has high sensitivity in comparison with the comet assay. Employing this method, we were able to analyze relationships between anti-tumor effects and cell cycle perturbations. Therefore, $\gamma \mathrm{H} 2 \mathrm{AX}$ detection is a promising method of simply and rapidly identifying agents potentially effective against CCC.

\section{Competing interest}

The authors have no conflicts of interest to report.

\section{Author details}

'Department of Obstetrics and Gynecology, Iwate Medical University School of Medicine, 19-1, Uchimaru, Morioka, Iwate 020-8505, Japan. 'Department of Pathology, Iwate Medical University School of Medicine, Uchimaru, Morioka, Iwate 020-8505, Japan. ${ }^{3}$ Department of Anatomic Pathology, Hirosaki University Graduate School of Medicine, 5, Zaifu-cho, Hirosaki, Aomori 036-8562, Japan.

\section{Authors' contributions}

ET participated in all aspects of the study, from design to clinical and laboratory performance, and manuscript writing. TS participated in design, data analysis and drafting of the manuscript. AK participated in the design of the study and technical assistance. SK, TS and TS participated in design and analysis of clinical data. All authors have read and approved the manuscript.

Received: 20 April 2012 Accepted: 12 June 2012

Published: 12 June 2012

\section{References}

1. Sugiyama T, Kamura T, Kigawa J, Terakawa N, Kikuchi Y, Kita T, Suzuki M, Sato I, Taguchi K: Clinical characteristics of clear cell carcinoma of the ovary. Cancer 2000, 88:2584-2589.

2. McGuire WP, Hoskins WJ, Brady MF, Kucera PR, Partridge EE, Look KY, ClarkePearson DL, Davidson M: Cyclophosphamide and cisplatin compared with paclitaxel and cisplatin in patients with stage III and stage IV ovarian cancer. N Engl J Med 1996, 334:1-6.

3. Ozols RF, Bundy BN, Greer BE, Fowler JM, Clarke-Pearson D, Burger RA, Mannel RS, DeGeest K, Hartenbach EM, Baergen R, Gynecologic Oncology Group: Phase III trial of carboplatin and paclitaxel compared with cisplatin and paclitaxel in patients with optimally resected stage III ovarian cancer: a Gynecologic Oncology Group study. J Clin Oncol 2003, 21:3194-3200

4. Sugiyama T, Fujiwara K: Clear cell carcinoma of the ovary. In American Society of Clinical Oncology 2007 educational book. Edited by Govindan R. Alexandria, VA:; 2007:318-322

5. Takano M, Kikuchi Y, Yaegashi N, Suzuki M, Tsuda H, Sagae S, Udagawa Y, Kuzuya K, Kigawa J, Takeuchi S, Tsuda H, Moriya T, Sugiyama T: Adjuvant chemotherapy with irinotecan hydrochloride and cisplatin for clear cell carcinoma of the ovary. Oncol Rep 2006, 16:1301-1306.

6. Takano M, Sugiyama T, Yaegashi N, Suzuki M, Tsuda H, Sagae S, Udagawa Y, Kuzuya K, Kigawa J, Takeuchi S, Tsuda H, Moriya T, Kikuchi Y: Progressionfree survival and overall survival of patients with clear cell carcinoma of the ovary treated with paclitaxel-carboplatin or irinotecan-cisplatin: retrospective analysis. Int J Clin Oncol 2007, 12:256-260.

7. Nishino K, Aoki Y, Amikura T, Obata H, Sekine M, Yahata T, Fujita K, Tanaka K. Irinotecan hydrochloride (CPT-11) and mitomycin $C$ as the first line chemotherapy for ovarian clear cell adenocarcinoma. Gynecol Oncol 2005, 97:893-897.

8. Dickey JS, Redon CE, Nakamura AJ, Baird BJ, Sedelnikova OA, Bonner WM: H2AX: functional roles and potential applications. Chromosoma 2009, 118:683-692.

9. Fragkos $M$, Jurvansuu J, Beard $P$ : $H 2 A X$ is required cell cycle arrest via the p53/p21 pathway. Mol Cell Biol 2009, 29:2828-2840.

10. Bonner WM, Redon CE, Dickey JS, Nakamura AJ, Sedelnikova OA, Solier S, Pommier Y: $Y H 2 A X$ and cancer. Nat Rev Cancer 2008, 8:957-967.

11. Itamochi H, Kigawa J, Sultana H, Iba T, Akeshima R, Kamazawa S, Kanamori $Y$, Terakawa N: Sensitivity to anticancer agents and resistance mechanisms in clear cell carcinoma of the ovary. Jpn J Cancer Res 2002, 93:723-728. 
12. Zwelling LA, Kohn KW: Mechanism of action of cisDichlorodiammineplatinum (II). Cancer Treat Rep 1979, 63:1439-1444.

13. Okuma Y, Kiguchi K, Koshitaka Y, Okamura A, Ishiwata I, Kondo H, Ishizuka B, Tadokoro M: Correlation between expression of oncogene products and resistance to anticancer drugs in cultured ovarian cancer cell lines. Hum Cell 2003, 16:131-139.

14. Rowinsky EK, Donehower RC, Jones RJ, Tucker RW: Microtubule changes and cytotoxicity in leukemic cell lines treated with Taxol. Cancer Res 1988, 48:4093-4100.

15. Takahashi M, Kigawa J, Minagawa Y, Itamochi H, Shimada M, Kamazawa S, Sato $S$, Akeshima R, Terakawa N: Sensitivity to paclitaxel is not related to p53-dependent apoptosis in ovarian cancer cells. Eur J Cancer 2000, 36:1863-1868.

16. Ho ES, Lai CR, Hsieh YT, Chen JT, Lin AJ, Hung MH, Liu FS: p53 mutation is infreq1uent in clear cell carcinoma of the ovary. Gynecol Oncol 2001, 80:189-193.

17. Enomoto T, Kuragaki C, Yamasaki M, Sugita N, Otsuki Y, Ikegami H, Matsuzaki M, Yamada T, Wakimoto A, Murata Y: Is clear cell carcinoma and mucinous carcinoma of the ovary sensitive to combination chemotherapy with paclitaxel and carboplatin? Proc Am Soc Clin Oncol 2003, 22:447(\#1797).

18. Katsumata N, Yasuda M, Takahashi F, Isonishi S, Jobo T, Aoki D, Tsuda H, Sugiyama T, Kodama S, Kimura E, Ochiai K, K Noda, Japanese Gynecologic Oncology Group: Dose-dense paclitaxel once a week in combination with carboplatin every 3 weeks for advanced ovarian cancer: a phase 3 , open-label, randomized controlled trial. Lancet 2009, 374:1331-1338

19. Hsiang YH, Liu LF, Wall ME, Wani MC, Nicholas AW, Manikumar G, Kirschenbaum S, Silber R, Potmesil M: DNA topoisomerase-I mediate DNA cleavage and cytotoxicity of camptothecin analogs. Cancer Res 1989, 49:4385-4389

doi:10.1186/1757-2215-5-16

Cite this article as: Takatori et al:: Are platinum agents, paclitaxel and irinotecan effective for clear cell carcinoma of the ovary? DNA damage detected with $\mathrm{yH} 2 \mathrm{AX}$ induced by anticancer agents. Journal of Ovarian Research 2012 5:16.

\section{Submit your next manuscript to BioMed Central and take full advantage of:}

- Convenient online submission

- Thorough peer review

- No space constraints or color figure charges

- Immediate publication on acceptance

- Inclusion in PubMed, CAS, Scopus and Google Scholar

- Research which is freely available for redistribution 